\title{
Front Matter: Volume 10140
}

, "Front Matter: Volume 10140," Proc. SPIE 10140, Medical Imaging 2017: Digital Pathology, 1014001 (5 April 2017); doi: 10.1117/12.2270372

SPIE. Event: SPIE Medical Imaging, 2017, Orlando, Florida, United States 


\title{
PROGRESS IN BIOMEDICAL OPTICS AND IMAGING
}

Vol. 18 No. 54

\section{Medical Imaging 2017 \\ Digital Pathology}

\author{
Metin N. Gurcan \\ John E. Tomaszewski \\ Editors
}

12-13 February 2017
Orlando, Florida, United States

Sponsored by

SPIE

Co-sponsored by

Alpinion Medical Systems (United States)

Cooperating Organizations

AAPM-American Association of Physicists in Medicine (United States)

APS-American Physiological Society (United States)

IFCARS-International Foundation for Computer Assisted Radiology and Surgery (Germany)

Medical Image Perception Society (United States)

Radiological Society of North America (United States)

Society for Imaging Informatics in Medicine (United States)

World Molecular Imaging Society

The DICOM Standards Committee

Published by

SPIE

Volume 10140 
The papers in this volume were part of the technical conference cited on the cover and title page. Papers were selected and subject to review by the editors and conference program committee. Some conference presentations may not be available for publication. Additional papers and presentation recordings may be available online in the SPIE Digital Library at SPIEDigitallibrary.org.

The papers reflect the work and thoughts of the authors and are published herein as submitted. The publisher is not responsible for the validity of the information or for any outcomes resulting from reliance thereon.

Please use the following format to cite material from these proceedings:

Author(s), "Title of Paper," in Medical Imaging 2017: Digital Pathology, edited by Metin N. Gurcan, John E. Tomaszewski, Proceedings of SPIE Vol. 10140 (SPIE, Bellingham, WA, 2017) Seven-digit Article CID Number.

ISSN: 1605-7422

ISSN: 2410-9045 (electronic)

ISBN: 9781510607255

ISBN: 9781510607262 (electronic)

Published by

SPIE

P.O. Box 10, Bellingham, Washington 98227-0010 USA

Telephone +1 3606763290 (Pacific Time) · Fax +1 3606471445

SPIE.org

Copyright @ 2017, Society of Photo-Optical Instrumentation Engineers.

Copying of material in this book for internal or personal use, or for the internal or personal use of specific clients, beyond the fair use provisions granted by the U.S. Copyright Law is authorized by SPIE subject to payment of copying fees. The Transactional Reporting Service base fee for this volume is $\$ 18.00$ per article (or portion thereof), which should be paid directly to the Copyright Clearance Center (CCC), 222 Rosewood Drive, Danvers, MA 01923. Payment may also be made electronically through CCC Online at copyright.com. Other copying for republication, resale, advertising or promotion, or any form of systematic or multiple reproduction of any material in this book is prohibited except with permission in writing from the publisher. The CCC fee code is $1605-7422 / 17 / \$ 18.00$.

Printed in the United States of America.

Publication of record for individual papers is online in the SPIE Digital Library.

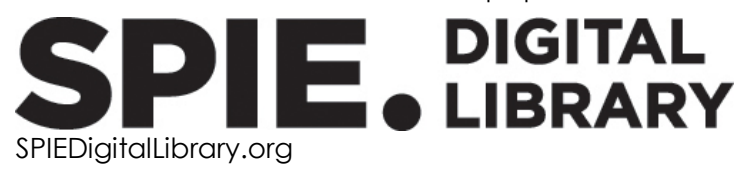

Paper Numbering: Proceedings of SPIE follow an e-First publication model. A unique citation identifier (CID) number is assigned to each article at the time of publication. Utilization of CIDs allows articles to be fully citable as soon as they are published online, and connects the same identifier to all online and print versions of the publication. SPIE uses a seven-digit CID article numbering system structured as follows:

- The first five digits correspond to the SPIE volume number.

- The last two digits indicate publication order within the volume using a Base 36 numbering system employing both numerals and letters. These two-number sets start with 00, 01, 02, 03, 04, $05,06,07,08,09,0 A, 0 B \ldots$. OZ, followed by 10-1Z, 20-2Z, etc. The CID Number appears on each page of the manuscript. 


\title{
Contents
}

\author{
vii Authors \\ ix Conference Committee \\ xi Introduction \\ xiii 2017 Medical Imaging Award Recipients
}

SESSION 1 EMERGING TECHNOLOGIES

1014002 Determining local and contextual features describing appearance of difficult to identify mitotic figures [10140-1]

1014003 Fast clustering in linear 1D subspaces: segmentation of microscopic image of unstained specimens [10140-2]

1014004 Applications of QCL mid-IR imaging to the advancement of pathology [10140-3]

1014005 Data-driven sampling method for building 3D anatomical models from serial histology [10140-4]

1014006 Automatic evaluation of skin histopathological images for melanocytic features [10140-5]

\section{SESSION 2 DETECTION AND SEGMENTATION}

1014007 Automated wholeslide analysis of multiplex-brightfield IHC images for cancer cells and carcinoma-associated fibroblasts [10140-6]

1014008 Lumen-based detection of prostate cancer via convolutional neural networks [10140-7]

1014009 Hierarchical patch-based co-registration of differently stained histopathology slides [10140-8]

10140 OA Automated high-grade prostate cancer detection and ranking on whole slide images [10140-9]

$10140 \mathrm{OB}$ Automated plasmodia recognition in microscopic images for diagnosis of malaria using convolutional neural networks [10140-10]

10140 OC A model of tumor architecture and spatial interactions with fumor microenvironment in breast carcinoma [10140-11] 
10140 OD Identification and characterization of neutrophil extracellular trap shapes in flow cytometry [10140-12]

10140 OE FOXP3-stained image analysis for follicular lymphoma: optimal adaptive thresholding with maximal nucleus coverage [10140-13]

10140 OF Context-sensitive patch histograms for detecting rare events in histopathological data [10140-14]

$101400 \mathrm{~A}$ Automatic computational labeling of glomerular textural boundaries [10140-15]

$10140 \mathrm{OH} \quad$ Convolutional neural networks for prostate cancer recurrence prediction [10140-16]

\section{SESSION 4 KEYNOTE AND TRENDS}

$10140 \mathrm{Ol}$ Leveraging unsupervised training sets for multi-scale compartmentalization in renal pathology [10140-17]

$10140 \mathrm{JJ}$ A computational framework to detect normal and tuberculosis infected lung from $\mathrm{H}$ and $\mathrm{E}$ stained whole slide images [10140-18]

10140 OK Evaluation of nucleus segmentation in digital pathology images through large scale image synthesis [10140-19]

POSTER SESSION

$101400 \mathrm{M} \quad$ Automated epidermis segmentation in histopathological images of human skin stained with hematoxylin and eosin [10140-21]

$10140 \mathrm{ON} \quad$ Automated cancer stem cell recognition in $\mathrm{H}$ and $\mathrm{E}$ stained tissue using convolutional neural networks and color deconvolution [10140-22]

1014000 Convolutional neural networks for an automatic classification of prostate tissue slides with high-grade Gleason score [10140-23]

$10140 \mathrm{OP} \quad$ Heterogeneity characterization of immunohistochemistry stained tissue using convolutional autoencoder [10140-24]

$101400 Q \quad$ A computational study on convolutional feature combination strategies for grade classification in colon cancer using fluorescence microscopy data [10140-25]

10140 OR Evaluating color performance of whole-slide imaging devices by multispectral-imaging of biological tissues [10140-26]

10140 OS Automatic Gleason grading of $\mathbf{H}$ and E stained microscopic prostate images using deep convolutional neural networks [10140-27] 
10140 ОT Integrative analysis on histopathological image for identifying cellular heterogeneity [10140-29]

$10140 \mathrm{OU}$ Extraction of glomeruli in whole slide imaging of kidney biopsy specimens [10140-30]

$10140 \mathrm{OV}$ Unsupervised segmentation of $\mathrm{H}$ and $\mathrm{E}$ breast images [10140-31]

$10140 \mathrm{OW}$ Optimized color decomposition of localized whole slide images and convolutional neural network for intermediate prostate cancer classification [10140-32]

10140 OY Panning artifacts in digital pathology images (Cum Laude Poster Award) [10140-34]

$10140 \mathrm{OZ}$ Tissue classification of liver pathological tissue specimens image using spectral features [10140-36]

1014010 Color normalization of histology slides using graph regularized sparse NMF [10140-37]

1014011 Frequency analysis of gaze points with CT colonography interpretation using eye gaze tracking system [10140-38]

1014013 Content-based histopathological image retrieval for whole slide image database using binary codes [10140-40] 
Proc. of SPIE Vol. $101401014001-6$

Downloaded From: https://www.spiedigitallibrary.org/conference-proceedings-of-spie on 26 Apr 2023 Terms of Use: https://www.spiedigitallibrary.org/terms-of-use 


\section{Authors}

Numbers in the index correspond to the last two digits of the seven-digit citation identifier (CID) article numbering system used in Proceedings of SPIE. The first five digits reflect the volume number. Base 36 numbering is employed for the last two digits and indicates the order of articles within the volume. Numbers start with 00, 01, 02, 03, 04, 05, 06, 07, 08, 09, OA, OB...0Z, followed by 10-12, 20-2Z, etc.

\author{
Abe, Tokiya, OU \\ Ablove, Tova, 05 \\ Aichinger, Wolfgang, ON \\ Andersson, Emilia, 07 \\ Andersson, Mats, 00 \\ Antulov-Fantulin, Nino, 03 \\ Arora, Ashish, $\mathrm{OH}$ \\ Arvidsson, Ida, OS \\ Aström, Kalle, OS \\ Atzori, Manfredo, 00 \\ Avanaki, Ali R. N., OY \\ Badano, Aldo, OR \\ Baust, Maximilian, OF \\ Beamer, Gillian, 0J \\ Ben Cheikh, Bassem, OC \\ Benz, Michaela, OB, ON \\ Bird, Benjamin, 04 \\ Bjartell, Anders, OS \\ Bor-Angelier, Catherine, OC \\ Brbić, Maria, 03 \\ Bredno, Joerg, 07 \\ Brennan, Patrick C., 02 \\ Cetin, A. Enis , ON \\ Cetin-Atalay, Rengul, ON \\ Chang, Young Hwan, OT \\ Chen, W., OE \\ Chen, Xinjian, 03 \\ Cheng, Wei-Chung, OR \\ Chowdhury, Aritra, $0 Q$ \\ Danforth, Theresa, 05 \\ Diaz, Kristians, OF \\ Doi, Kunio, 11 \\ Doyle, Scott, 05 \\ Dyduch, Grzegorz, OM \\ Emmons, Tiffany, OD \\ Espig, Kathryn S., OY \\ Eurén, Kristian, 00 \\ Gabrani, Maria, OP \\ Gandomkar, Ziba, 02 \\ Gann, Peter H., OH \\ Gao, Yi, OK, OW \\ Ginley, Brandon, OD, OG \\ Gray, Joe W., OT \\ Grimm, Oliver, 07 \\ Gryanik, Alexander, OB \\ Gummeson, Anna, OS \\ Gupta, Sanchit, $\mathrm{OH}$ \\ Gurcan, Metin N., OE, OJ \\ Guzman, Grace, 04
}

Hasegawa, Madoka, $\mathrm{OZ}$

Hashiguchi, Akinori, OU

Hashimoto, Emi, $\mathrm{OZ}$

Hashizume, Makoto, $\mathrm{OZ}$

Hasserjian, R. P., OE

Hedlund, Martin, 00

Hewitt, Stephen M., 08

Heyden, Anders, OS

Honda, Natsuki, OU

Hope, Tyna A., OV

Hoseini Alinodehi, S. Pourya, 06

Huang, Chao-Hui, OA

Ishikawa, Masahiro, OU, OZ

Iwamoto, Chika, $\mathrm{OZ}$

Jaworek-Korjakowska, Joanna, OM

Jiang, Zhiguo, 13

Jiménez del Toro, Oscar, 00

Johnson, Brett, OT

Kimpe, Tom R. L., OY

Kłeczek, Paweł, OM

Kobayashi, Naoki, OU, $\mathrm{OZ}$

Komagata, Hideki, OZ

Koosha, Mohaddeseh, 06

Kopriva, Ivica, 03

Krappe, Sebastian, OB, ON

Krzyzanowska, Agnieszka, OS

Kumar, Abhay, $\mathrm{OH}$

Kumar, Neeraj, $\mathrm{OH}$

Kurc, Tahsin, OK

Kwak, Jin Tae, 08

Lanciault, Christian, OY

Lorsakul, Auranuch, 07

Louissaint, A., OE

Lozanski, G., OE

Lutnick, Brendon, 01

Ma, Yibing, 13

Margolin, Adam, OT

Mello-Thoms, Claudia, 02

Mochidome, Naoki, $\mathrm{OZ}$

Müller, Henning, 00

Münzenmayer, Christian, OB, ON

Navab, Nassir, OF

Niazi, M. Khalid Khan, OJ

Nicolescu, Mircea, 06

Oda, Yoshinao, $\mathrm{OZ}$

Ogura, Toshihiro, 11

Ohlsson, Mattias, OS

Ohuchida, Kenoki, $\mathrm{OZ}$

Okajima, Mika, 11 
Otálora, Sebastian, 00

Overgaard, Niels Christian, OS

Pennell, M., OE

Prisacari, Bogdan, OP

Racoceanu, Daniel, OA, OC

Rönnquist, Peter, 00

Sade, Hadassah, 07

Safaei Naraghi, Zahra, 06

Sahiner, B., OE

Sakamoto, Michiie, OU

Saleheen, Firdous, OR

Saltz, Joel, OK

Salunke, Snehal Ulhas, 05

Santamaria-Pang, Alberto, $\mathrm{OQ}$

Sarder, Pinaki, OD, OG, Ol

Sasankan, Prabhu, OD

Sato, Mitsuru, 11

Schmidt, Günter, 09

Schonfeld, Dan, 10

Segal, Brahm H., OD

Senaras, C., OE

Sethi, Amit, $\mathrm{OH}, 10$

Sevinsky, Christopher J., OQ

Sha, Lingdao, 10

Shana'ah, A., OE

Shi, Huagiang, 13

Shinoda, Kazuma, $\mathrm{OZ}$

Sreedhar, Hari, 04

Stamminger, Marc, OB, ON

Tadeusiewicz, Ryszard, OM

Tamashiro, Wataru, 11

Tannenbaum, Allen, OK

Tannich, Egbert, OB

Thibault, Guillaume, ОT

Tolić, Dijana, 03

Tomaszewski, John E., 05, 0G, 이

Tsutsumi, Shoko, 11

Üner, Aysegül, ON

Urban, Constantin, OD

Varma, Vishal K., 04

Vega Harring, Suzana, 07

Verma, Ruchika, $\mathrm{OH}$

Walsh, Michael J., 04

Wang, Fusheng, OK

Watanabe, Sumire, OU

Wegner, Christine, OB

Wen, Si, OK

Wild, Peter, OP

Wittenberg, Thomas, OB, ON

Xie, Fengying, 13

Xthona, Albert, OY

Yaffe, Martin J., OV

Yener, Bülent, OQ

Yigitsoy, Mehmet, 09

Yu, Xiaxia, OK

Zerhouni, Erwan, OP

Zhang, Haopeng, 13

Zhao, Tianhao, OK

Zhao, Yu, 13

Zheng, Yushan, 13
Zhong, Qing, OP

Zhou, Naiyun, OK, OW

Zhu, Wei, OK 


\title{
Conference Committee
}

\author{
Symposium Chairs
}

Berkman Sahiner, U.S. Food and Drug Administration (United States) Leonard Berliner, Weill Cornell Medical College (United States) and New York Methodist Hospital (United States)

\section{Conference Chairs}

Metin N. Gurcan, The Ohio State University Wexner Medical Center (United States)

John E. Tomaszewski, University at Buffalo (United States)

\section{Conference Program Committee}

Selim Aksoy, Bilkent University (Turkey)

Ulysses J. Balis, University of Michigan Health System (United States)

Rohit Bhargava, University of Illinois at Urbana-Champaign (United States)

Ulf-Dietrich Braumann, Hochschule für Technik, Wirtschaft und Kultur Leipzig (Germany)

Eric Cosatto, NEC Laboratories America, Inc. (United States)

Scott Doyle, Rutgers, The State University of New Jersey (United States)

Michael D. Feldman, The University of Pennsylvania Health System (United States)

David J. Foran, Rutgers Cancer Institute of New Jersey (United States)

Brandon D. Gallas, U.S. Food and Drug Administration (United States)

Marios A. Gavrielides, U.S. Food and Drug Administration (United States)

Tom R. L. Kimpe, Barco N.V. (Belgium)

Elizabeth A. Krupinski, The University of Arizona (United States)

Richard M. Levenson, University of California, Davis (United States)

Olivier Lezoray, Université de Caen Basse Normandie (France)

Anant Madabhushi, Case Western Reserve University (United States)

Derek R. Magee, University of Leeds (United Kingdom)

Anne L. Martel, Sunnybrook Research Institute (Canada)

Erik Meijering, Erasmus MC (Netherlands)

James P. Monaco, Inspirata, Inc. (United States)

Mehdi Moradi, IBM Research - Almaden (United States)

Bahram Parvin, Lawrence Berkeley National Laboratory (United States)

Josien P. W. Pluim, Image Sciences Institute (Netherlands)

Nasir M. Rajpoot, The University of Warwick (United Kingdom)

Gustavo Kunde Rohde, Carnegie Mellon University (United States)

Berkman Sahiner, U.S. Food and Drug Administration (United States)

Chukka Srinivas, Ventana Medical Systems, Inc. (United States)

Darren Treanor, University of Leeds (United Kingdom) 
Jeroen van der Laak, Radboud University Nijmegen Medical Center (Netherlands)

Aaron D. Ward, The University of Western Ontario (Canada)

Martin J. Yaffe, Sunnybrook Research Institute (Canada)

Bülent Yener, Rensselaer Polytechnic Institute (United States)

\section{Session Chairs}

1 Emerging Technologies

Brandon D. Gallas, U.S. Food and Drug Administration (United States)

Scott Doyle, University at Buffalo (United States)

2 Detection and Segmentation

Elizabeth A. Krupinski, Emory University School of Medicine (United States)

Mehdi Moradi, IBM Research - Almaden (United States)

3 Precision Medicine and Grading

John E. Tomaszewski, University at Buffalo (United States)

Selim Aksoy, Bilkent University (Turkey)

4 Keynote and Trends

Michael D. Feldman, The University of Pennsylvania Health System

(United States)

Martin Yaffe, Sunnybrook Research Institute (Canada) 


\section{Introduction}

This is the fifth year of the Digital Pathology Conference that was introduced at SPIE's Medical Imaging Symposium in Orlando, FL in 2013. Every year since that inaugural event we have seen increased interest in cell and tissue imaging which has made Digital Pathology one of the distinguished conferences at the Medical Imaging Symposium. The quality of the presented talks, posters, and the resulting papers, like in the previous years, continues to be outstanding. This is mainly thanks to our community of digital pathology image scientists and diagnosticians who submit some of their very best work to this conference. We are grateful for their good work. We are also thankful for all the hard work of our program committee, who carefully conducted a rigorous peer-review process to ensure that only top papers are selected for presentation at the meeting.

The fifth Digital Pathology Conference took place on February 12 and 13 at the Renaissance SeaWorld, in Orlando, Florida, United States. A plenary talk was given on February $13^{\text {th }}$ by Dr. Anant Madabhushi entitled "Image based risk score predictor: predicting disease aggressiveness using sub-visual cues from image data." Dr. Madabhushi is an image scientist and one of the leaders in the field. Dr. Madabhushi discussed the motivation and rationale for developing image and fused data biomarkers in oncology. He illustrated the opportunity to mine both radiological and high-resolution histopathological images for data which supports both prognostic and predictive modeling in cancer. The audience was left with the clear message that there is critical information about the relationships amongst tumor cells and their host environment which can only be obtained through the use of quantitative image analytics. The keynote talk drew over 200 attendees from all the various conferences as part of the SPIE Medical imaging symposium.

A total of 41 papers were presented during the course of the meeting in both oral and poster form. The sessions included Trends, Precision Medicine and Grading, Detection and Segmentation, Machine Learning, Emerging Technologies.

We would like to acknowledge the excellent work in the following papers:

\section{Conference finalists of the Robert F. Wagner Best Student Paper Award for Digital Pathology (10140)}

Optimized color decomposition of localized whole slide images and convolutional neural network for intermediate prostate cancer classification Paper 10140-32

Student Author: Naiyun Zhou, Stony Brook Univ. (USA) 
Tissue classification of liver pathological tissue specimens image using spectral features

Paper 10140-36

Student Author: Emi Hashimoto, Saitama Medical University, Saitama (Japan)

\section{Poster Awards}

\section{Cum Laude Poster Award}

Panning artifacts in digital pathology images,

Ali R. N. Avanaki, Barco, Inc. (USA) [10140-34]

\section{Honorable Mention Poster Award}

Topological descriptors for quantitative prostate cancer morphology analysis, Peter J. Lawson, Tulane Univ. (USA); Eric Berry, Montana State Univ. (USA); J. Quincy Brown, Tulane Univ. (USA); Brittany T. Fasy, Montana State Univ. (USA); Carola Wenk, Tulane Univ. (USA) [10140-33]

The continued success of the Digital Pathology conference is in no small part due to the outstanding efforts of the program committee who carefully constructed the program, the Conference Chairs Drs. Berkman Sahiner and Leonard Berliner, and SPIE management who kindly guided us through all the many steps of the program organization.

Next year the Medical Imaging meeting will take place in Houston, TX. We look forward to seeing you there for another successful conference.

Metin N. Gurcan

John E. Tomaszewski 


\section{Medical Imaging Award Recipients}

\section{Robert F. Wagner Best Student Paper Award}

Robert F. Wagner was an active scientist in the SPIE Medical Imaging meeting, starting with the first meeting in 1972 and continuing throughout his career. He ensured that the $\mathrm{BRH}$, and subsequently the $\mathrm{CDRH}$, was a sponsor for the early and subsequent Medical Imaging meetings, helping to launch and ensure the historical success of the meeting. The Robert F. Wagner All-Conference Best Student Paper Award (established 2014) is acknowledgment of his many important contributions to the Medical Imaging meeting and his many important advances to the field of medical imaging.

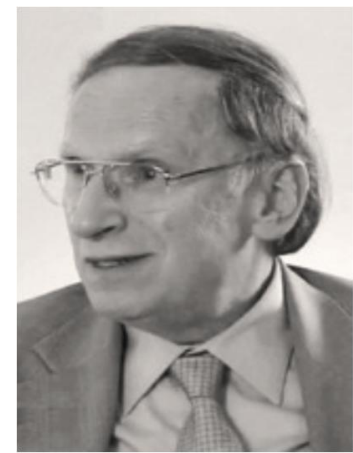

This award is cosponsored by:

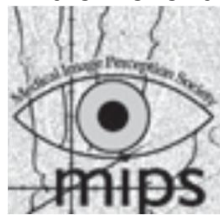

The Medical Image Perception Society

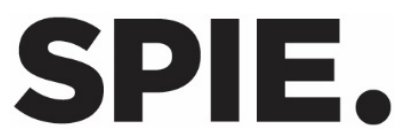

\section{Recipients:}

First Place: Direct measurement of Lubberts effect in CsI:Tl scintillators using single x-ray photon imaging (10132-8)

A. Howansky, A. R. Lubinsky, Stony Brook Univ. (United States); S. K. Ghose, Brookhaven National Lab. (United States); K. Suzuki, Hamamatsu Photonics K.K. (Japan); W. Zhao, Stony Brook Univ. (United States)

Second Place: Evaluation of a high-resolution patient-specific model of the electrically stimulated cochlea (10135-21)

A. Cakir, Vanderbilt Univ. (United States); R. T. Dwyer, Vanderbilt Univ. Medical Ctr. (United States); J. H. Noble, Vanderbilt Univ. (United States) 
Proc. of SPIE Vol. 10140 1014001-14 Downloaded From: https://www.spiedigitallibrary.org/conference-proceedings-of-spie on 26 Apr 2023
Terms of Use: https://www.spiedigitallibrary.org/terms-of-use 